\title{
Wobblies and Mexican Workers in Mining and Petroleum, 1905-1924
}

\author{
NORMAN CAULFIELD
}

\begin{abstract}
Summary: The Industrial Workers of the World (IWW), or "Wobblies", represented a transitional stage in Mexican labor movement history. The Wobblies enjoyed support from workers because their philosophy corresponded to the Mexican labor movement's deeply-rooted anarchosyndicalist traditions. While cooperating with Mexican radical labor organizations, the IWW advocated workers' control, better pay, conditions, and union recognition. In mining and petroleum, the IWW built upon the earlier organizational efforts of mutual and gremial organizations. And, although the Wobblies failed to establish a permanent foothold inside Mexico, their efforts resulted in the eventual organization of industry-wide unions.
\end{abstract}

\section{INTRODUCTION}

Mexico's modernization under the rule of Porfirio Díaz (1876-1911) generated a relationship between organized labor in the United States and Mexico. The interaction between Mexican workers, their organizations, and the US labor movement resulted from shared levels of industrial development among regional economies that straddled the international border. Beginning in the 1880 s major US investments in railroads, mining, petroleum and agriculture linked the future of the northern Mexican economy with the accelerated economic development of the western United States. Uniting the two economies initiated a cross-border flow of Mexican migrants, laborers who joined American workers and protested the abusive practices and arbitrary methods used by turn of the century North American capitalist management. This protest acted as a catalyst for forging the cross-class unity that eventually produced the 1910 Mexican Revolution. In the process, Mexican workers, particularly those who toiled in mining and petroleum, fell under the influence of the Industrial Workers of the World (IWW) or "Wobblies" as they were called.

While working and living in the United States, Mexicans did not distance themselves from the momentous social change occurring in Mexico. They continued to interact with Mexico through their own periodic returns to the homeland, participation in community life and associations inside the numerous exiled Mexican political movements in 
the United States. The most important of these organizations was the Partido Liberal Mexicano - Mexican Liberal Party (PLM). Begun as an organization dedicated to revolutionary change inside Mexico, it became immersed in American radicalism. Exiled to the United States in 1904, its leaders Ricardo and Enrique Flores Magón gained widespread support from Mexican workers employed in labor-intensive sectors of the American economy. The IWW had a profound influence in the shaping of magonista philosophy. ${ }^{1}$

The IWW advocated anarchosyndicalism, which called for workers' control of industry and the building of a movement through a series of strikes waged around immediate demands for better pay and conditions. For Mexican workers in mining and petroleum, workplace organization and the quest for immediate gains had revolutionary significance. The "bread and butter" issues combined with the promise of future workers' control struck a responsive chord among workers caught up in a nationalist revolution that sought to regain control from foreigners the nation's natural resources, productive systems and economic infrastructure. Within the context of Mexican nationalism and the revolution, the IWW gained acceptance among Mexican workers, even though it was foreign in origin.

The Wobblies also enjoyed support from Mexican workers because their philosophy corresponded to the Mexican labor movement's deeplyrooted anarchosyndicalist traditions. Inculcated by foreign organizers, most of whom were from Spain, the radical anarchosyndicalist tradition dominated Mexico's labor movement during the nineteenth century. Anarchism, nationalism, and anti-statism characterized the radical labor tradition. ${ }^{2}$ Despite government disfavor, radicals representing these tendencies organized industrial workers in the 1860 s and 1870 s. By 1880 radical anarchosyndicalists had built a 50,000 member Congress of Mexican Workers that joined the Anarchist International headquartered in Amsterdam. The Diaz government and the elite regime that emerged during the 1910 Revolution opposed this radical tendency. Nonetheless, it remained a strong current in the workers' movement throughout the revolution and the reconstruction period of the early 1920s. Its firm foothold within the working class opened the door for Wobbly organizing inside Mexico.

The Casa del Obrero Mundial also facilitated the IWW's activities in Mexico. During the revolution the Casa represented Mexican anarchosyndicalist traditions. It functioned as an open forum where union leaders

'For the IWW's influence on the Magonistas see W. Dirk Raat, Revoltosos: Mexico's Rebels in the United States, 1903-1923 (College Station, TX, 1981); Colin M. MacLachlan, Anarchism and the Mexican Revolution: The Political Trials of Ricardo Flores Magon in the United States (Berkeley, 1991); and Ward S. Albro, Alwaj's a Rebel: Ricardo Flores Magon and the Mlexican Revolution (Fort Worth, 1992).

2 John M. Hart, Anarchism and the Mexican Working Class, 1860-1931 (Austin, 1978). 
exchanged ideas, established principles and designed strategy and tactics. Like the IWW, the Casa emphasized workers' control over production and the use of the strike around immediate demands to better the lot of the working class. Based in Mexico City, during the revolution the Casa's direct participation in the armed struggle led to the expansion of its influence in peripheral industrial areas of the nation where it came into contact with the IWW. The Casa press regularly featured articles from IWW newspapers in the United States and "praised the principles of the organization". ${ }^{3}$ When the Casa declined as an organization, the IWW cooperated with anarchosyndicalists and other radical groups that later formed the Confederacion General de Trabajadores (CGT).

While a shared ideological tradition with Mexican working-class organizations played a significant role in the IWW's penetration of Mexico, its participation in Mexican workers' struggles on both sides of the border was more important. In 1903 Mexican miners in Arizona joined organizers from the Western Federation Miners (WFM) and protested poor pay, working conditions, and discrimination. ${ }^{4}$ In 1905 the WFM made up the core of the IWW's membership at its founding convention. In 1906 PLM organizers joined the WFM in leading Mexican miners on strike against the Rockefeller-controlled Greene Copper Company in Cananea, Sonora, inside Mexico. The Cananea incident is considered by most historians as the first battle of the revolution, and the events that transpired there facilitated the efforts of the IWW in organizing Mexican workers. ${ }^{5}$

From 1911 to 1924 the IWW carried out propaganda work among Mexicans with Spanish language newspapers printed in the United States, spreading the union's ideas to the mining communities of the Mexican north, and Tampico, the world's leading petroleum producing center. Beginning in 1916, the IWW, cooperating with the Casa del Obrero Mundial, enlisted the support of oil workers, stevedores, and construction workers in Tampico. The Wobblies also agitated among miners and smelter workers in Torreon, the states of Sonora, Coahuila, and Chihuahua. As early as 1912, the Wobblies had organized four locals in Gómez Palacio, and in Torreón, where they had established a strong union at

\footnotetext{
3 Philip S. Foner, The U.S. Labor Movement and Latin America: vol. 1 1846-1919 (South Hadley, Mass., 1988), p. 146.

"For the early struggles of Mexican miners in the United States see Phil Mellinger, "The Men Have Become Organizers': Labor Conflict and Unionization in the Mexican Mining Communities of Arizona, 1900-1915", Western Historical Quarterly, 3 (1992), pp. 323-348.

${ }^{3}$ Most historians of the Mexican Revolution call Cananea the beginning of the demise of the regime of Porfirio Diaz (1876-1911). For this interpretation see Rodney D. Anderson, Outcasts In Their Own Land: Mexican Industrial Workers, 1906-1911 (DeKalb, 1976); Ramón Eduardo Ruiz, The Great Rebellion: Mexico, 1905-1924 (New York, 1980); John Mason Hart, Revolutionary Mexico: The Coming and the Process of the Mexican Revolution (Berkeley, 1987).
} 
the metal smelter of the Compañía Metalúrgica de Torreón. ${ }^{6}$ By 1917, the IWW had solidified its support among Mexican miners working in the south-western United States, and through the early 1920s it continued to thrive in Mexican mining districts, especially in Chihuahua.

As in the US, the IWW rejected the American Federation of Labor's (AFL) concept of collective bargaining, or what one historian has called the "institutionalization of state control" over the labor movement." Instead, like other Mexican labor organizations in the anarchosyndicalist tradition, the IWW defended union autonomy. ${ }^{8}$ The Wobblies especially rejected the policies of the Confederacion Regional Obrera Mexicana (CROM), an organization that emulated the goals and philosophy of the AFL and encouraged government-labor cooperation. In mining and petroleum, the Wobblies exercised an important role by building on the work of groups like the Union Minera Mexicana, and the numerous mutualist and worker education groups that emerged with the development of the Tampico oil region. ${ }^{9}$ Many of these organizations became immersed in the politics surrounding the revolution. Some supported Francisco Madero against the rule of Porfirio Diaz with the hope that their participation in the maderista movement would improve the lot of Mexican workers. Other organizations such as the Union Minera Mexicana influenced the writing of the 1917 Constitution which gave Mexican workers the world's most advanced labor code of the time.

Through its own efforts and cooperation with Mexican labor organizations, the IWW helped to establish the Mexican working class as a

"For the IWW in Torreon, see "trabajo y produccion" in Luz (Mexico City), 29 April 1917.

'Gregg Andrews, Shoulder to Shoulder? The American Federation of Labor, The United States, and the Mexican Revolution 1910-1924 (Berkeley, 1991). Andrews is emphatic in his analysis of the Mexican Revolutioin that radical groups like the IWW worried the Mexican and US governments because of the inroads the organization made among Mexican workers, especially miners in the border regions. In addition, Andrews claims that the IWW was part of the Mexican radical movement that opposed Samuel Gompers, AFL-style unionism, and the Mexican government's efforts to establish that brand of unionism south of the border.

- John M. Hart, Anarchism, pp. 12-18. Hart explains that the syndicalism espoused by Mexican industrial workers was rooted in the nation's precapitalist agrarista movements which specifically demanded local autonomy from centralized government. He attributes the success of the agraristes to their ability to raise demands that were compatible with the values, traditions and aspirations of the sedentary-indigenous people, which incorporated egalitarianism, a distrust of government officials, absentee landlords and a suspicion of politics. Within this context, syndicalist groups like the IWW that rejected politics and centralized authority gained support among first-generation Mexican industrial workers as they attempted to confront the conditions of their new environment.

- For mutualist and gremial organization in the mining industry see Federico Besserer. Victoria Novelo and Juan Luis Sariego, El sindicalismo minero en Aldrico, 1900-1952 (Mexico, DF, 1983), pp. 23-25; for early mutualist and gremial organizations in the Tampico region see S. Leif Adelson, "Historia social del los obreros industriales de Tampico, 1906-1919" (doctoral thesis, El Colegio de México, 1982), pp. 167-227. 
significant social group. In Mexico and elsewhere, the Wobblies represented a transitional stage in labor movement history; one between early craft unionism and industry-wide organization. Through its focus on immediate worker demands and long-range goals, such as workers' control of industry, the IWW struck a responsive chord among workers in perhaps the most crucial period of the international labor movement.

\section{THE IWW AND MEXICAN OIL WORKERS}

Syndicalists began organizing Tampico workers around 1915 when representatives of the Mexico City Casa del Obrero Mundial established a branch there. Mutualist and worker organizations called gremios that predated Tampico's industrial expansion established important precedents that facilitated the Casa's entrance into the region. Especially important were the early mutualist organizations such as la Benito Juarez, Hermanos del Trabajo, Union y Concordia and Hidalgo. ${ }^{10}$ The mutualist organizations established funds for medical care, burials, and pay for workers hurt on the job. The membership of the mutualistas as they were called, consisted of artisans, and in some cases included middle-class professionals and merchants. Education and specifically "night-school" instruction was a major function of the mutualistas. Through the mutualistas, workers studied literature, politics, economics and foreign languages, all free of charge. The ultimate goal of mutualistas like Regeneración and el Gremio Maritimo Fluvial from the Tampico industrial suburb of Doña Cecilía, hoped to find "Igualidad por la Instruccion" (equality through instruction). ${ }^{11}$ The mutualist tradition, through its stress on education and worker identity, provided the framework for Casa organizing.

By 1912 the existing mutualistas had transformed themselves from primarily educational groups to organizations of action. Instrumental in this process were the gremios of dockworkers and stevedores. Leading the dockworkers was Samuel Kelly, an ex-sailor and fish vendor. Kelly advocated organization that would defend the "general interests" of port and maritime workers. ${ }^{12}$ Kelly and the gremios agitated on two fronts. Hoping to achieve some leverage against the foreign companies, the gremios participated in the maderista movement. Ultimately, however, to better the economic situation of port and maritime workers, Kelly and the Gremio Unido de Alijadores attacked the hated contract system that involved "middle men", and instead promoted the direct bargaining for employment between the workers and the ship captains. ${ }^{23}$ The result

\footnotetext{
to Ibid., p. 167.

"Ibid., p. 169.

12 Ibid., p. 187.

"lbid.
} 
was that in 1913, for the first time, Kelly and the Gremio Unido de Alijadores engaged Tampico workers in "direct action" to improve job conditions and wages. ${ }^{14}$ By 1916, the year Casa organizers arrived in Tampico, the region's workers already had organized themselves into Gremios Unidos, such as the one at the Waters-Pierce Oil Corporation. Tampico workers were moving from mutualist objectives and methods and replacing them with the goals of higher wages and better conditions, and employing the tactics of direct action to achieve them. ${ }^{15}$

In 1916 the IWW joined Casa organizers when the Marine Transport Workers' Union (MTW) arrived in Tampico on the C. A. Canfield from the United States Atlantic seaport of Philadelphia. Many MTW sailors spoke Spanish and originated from either Spain or other Latin American countries. The Spanish speaking sailors joined the IWW by the hundreds. The AFL's International Seamen's Union had refused to organize them because they were foreign-born.

Although the US government successfully crushed most IWW unions during the hysteria surrounding World War I, the MTW remained intact because of the international scope of its activities. Throughout the 1920s the MTW's influence grew, especially in Latin America, where locals emerged in Mexico, Chile, Ecuador, Uruguay and Argentina. In Chile the MTW and the IWW played crucial roles in the early organization of stevedores, dockworkers and textile factory workers. In 1919 the MTW established a regional Latin American headquarters in Buenos Aires, and in 1924 it conducted an international conference of union seamen in Montevideo, Uruguay. ${ }^{16}$ In Tampico, the IWW and the Casa shared the same building, conducted meetings together, and jointly distributed syndicalist propaganda that eventually resulted in the organization of hundreds of workers. They issued demands for higher wages, better conditions, union recognition and autonomy. ${ }^{17}$

Work stoppages began to occur in Tampico during April 1916, when IWW leaders sent ultimatums to the petroleum and shipping companies.

14 lbid., pp. 187-210.

15 Ibid.

${ }^{16}$ For the IWW's role in organizing Chilean workers see Peter DeShazo, Urban Workers and Labor Unions in Chile, 1902-1927 (Madison, 1983). Information on the MTW's international meeting of union seamen can be found in Adolfo Garcla, "The Workers Look to Montevideo", Industrial Pioneer (Chicago), January 1925, p. 7.

$"$ The Casa's activities in Tampico are discussed in S. Leif Adelson, "Cultural Roots of Mexican Oil Workers in Tampico, 1910-1925", The Instimue of Latin American Studies, University of Texas at Austin (1988), p. 34. The MTW and IWW's arrival in the area and its cooperation with the Casa are highlighted in Solidarity (Cleveland), 3 February 1917; information on IWW and Casa activity in Tampico can also be found in National Archives and Records Administration, Washington, DC (hereafter cited as NARAW). State Department Records (hereafter cited as SD Records), Record Group 59 (hereafter cited as RG 59), 812.504/134; confidential letter from Department of Treasury agent, Wilbur Carr, to the Secretary of State, 27 August 1917. 
They demanded an eight-hour day and a minimum wage for all workers on the basis of gold to be paid at the highest rate of exchange. The demands won the workers' support because inflation and the declining value of the national currency continued to eat away at their standard of living. Neither the local military chiefs nor company management responded to the syndicalist leadership's ultimatums. The IWW then called for a strike. ${ }^{18}$

The first day of the strike unleashed the frustrations of hundreds of Tampico residents. Demonstrators looted dozens of stores in the central business district. The military reacted quickly and General Emiliano P. Nafarette, the local commander, sent detachments of infantry and mounted troops to disperse labor meetings, clear the streets, and arrest the leaders of the strike. The authorities acted aggressively because the strike had shut down the oil company and dozens of other public facilities. Several confrontations occurred between strikers and soldiers, resulting in the death of one striking worker. ${ }^{19}$

The next day General Nafarette hoped to diffuse the situation. He called for a conference of employers and labor representatives. During the meeting Nafarette advised IWW leaders to drop their demands. He asserted that he was in supreme command of the district and insisted that public order would be maintained at any cost. He also suggested that the strikers return to work the next morning, and that if this condition was met, he personally would accept a list of grievances for submission to the employers within the next ten days. Ricardo Treviño, representing the IWW and the workers, called off the strike and accepted Nafarette's terms. ${ }^{\text {o }}$

Despite the compromise, the IWW's actions and the state's use of military force fueled the organizational development and militant character of the region's working-class movement. In late 1916 Mexican IWW organizer Pedro Coria arrived in Tampico from Arizona, where he had been organizing miners and distributing IWW literature. In January 1917, Coria helped establish Tampico IWW union, MTW Local \#100. ${ }^{21}$

As inflation continued to eat away at Tampico workers' wages, the IWW and Casa demanded that the companies pay the workers in gold instead of the worthless paper currency issued by the government. On 23 April 1917, the IWW led employees of the British-owned Aguila Petroleum Company out on strike. They demanded payment of a minimum wage in gold and boldly called for the company to take immediate

"NARAW, SD Records, RG 59, 812.504/46; letter from American Consul, Claude I. Dawson to the Secretary of State, 6 April 1916.

19 Ibid.

${ }^{20} \mathrm{Ibid}$.

21 El Rebelde (Los Angeles), 3 February 1917; also see Solidarity (Cleveland), 10 February 1917. 
action or face the "consequences". When company officials refused to meet with a strike committee, strikers assaulted company managers and officials who tried to run operations.

When the British Consul petitioned authorities to arrest the leaders, workers shut down the American-owned Pierce Oil Corporation, assaulted company officials and drove off supervisory personnel. ${ }^{22}$ The strike then spread to the docks as stevedores, longshoremen, and boatmen prevented tankers from loading and unloading their cargo. ${ }^{23}$ The US Consul, Claude Dawson, demanded protection for the American companies from the local military commander. Dissatisfied with the slow response, he then requested military protection from the American ship, U.S.S. Annapolis, offshore in the Gulf of Mexico. ${ }^{24}$

Meanwhile, the US State Department worked through the American ambassador in Mexico City. The American government urged Mexican officials to pressure the Tampico military commander to take immediate action and protect American lives and property. ${ }^{25}$ After the Americans moved more naval vessels to Tampico, Mexican forces were finally put on alert. With American ships offshore, and Mexican military forces poised for an attack on the strikers, tensions rose within the Tampico community. Thousands of strikers filled the streets and public services ground to a halt. On 1 May, IWW leaders Ramón Parreno and Francisco Gamallo made speeches to large crowds in the city's central plaza that called for an end to "workers" exploitation".26

On the same day the strike spread to the Standard Oil and Texas companies, and the leadership demanded more salary increases. ${ }^{27}$ The IWW asked for a 50 per cent increase in wages and payment of salaries in Mexican gold, or United States money at the rate of exchange fixed by the government. As more workers became strikers, pickets armed themselves with clubs and physically prevented management and supervisory personnel from entering company facilities. The strikers were further emboldened when the American steamship Mexicana remained in Tampico's harbor because the ship's crew members refused to cross their picket line. ${ }^{28}$ In June the strike spread to the Huasteca Petroleum

2 NARAW, SD Records, RG 59, 812.504/81; telegram from Dawson to the Secretary of State, 23 April 1917.

23 lbid.

${ }^{24}$ Ibid., 812.504/82; 812.504/85; telegrams from Dawson to the Secretary of State, 24 and 26 April 1917.

${ }^{25}$ Ibid., 812.504/86; telegram from American Ambassador to the Secretary of State and Consul Dawson, 27 April 1917.

${ }^{26}$ Ibid., 812.504/87; telegram from Dawson to the Secretary of State, 30 April 1917.

27 Ibid., 812.504/91; telegram from the U.S.S. Tacoma to the Secretary of Navy, 2 May 1917.

2aid., 812.504/95; letter from Consul Dawson to the Secretary of State, 2 May 1917. 
Company, and labor leaders began to threaten a general strike if their demands for salary payment in gold or US currency were not met. ${ }^{29}$

On 16 July, maritime workers, boatmen, and dockworkers joined the strike when employers rejected the IWW's demands for higher pay. The strikers immediately paralyzed operations by shutting down three American-owned dredging vessels. Six days later a general strike of the Tampico area commenced when over 15,000 workers stopped all petroleum production. The Vice-President of Pierce Oil Corporation, Eben Richards, asked the United States government to protect company property and American lives. Meanwhile, workers in all Tampico refineries had walked off their jobs in sympathy with the maritime employees striking on the Pañuco River. The US State Department assured Richards that steps already had been taken by Mexican officials to control the situation. ${ }^{30}$

The general strike in the petroleum and shipping industries soon affected the entire Tampico community as street car workers suspended service, and ice-factories and electric light plants closed. Public speeches became more frequent in the city's central plaza. There Casa and IWW leaders attacked the Mexican government and the foreign companies. An atmosphere of intense debate and politicization filled the community's restaurants, saloons, and hotels.

As the crisis deepened, the foreign-owned companies and the American Consul blamed foreign agitators for precipitating the strike. They specifically identified the IWW, and claimed that its leaders intimidated "good" Mexican workers by threatening them with violence if they did not join the strike. ${ }^{31}$ Mexican Petroleum Company manager George Paddleford attempted to divide the strikers. He said that he would meet and negotiate with a committee of "regular workers" and not representatives of the IWW, whom he called "outside agitators". Paddleford also refused to negotiate with any team of workers until they complied with state Governor Alfredo Ricaut's proclamation that ordered them back on the job. Strikers ignored Ricaut and Paddleford and the shut down continued. ${ }^{32}$

\footnotetext{
Ibid., 812.504/107A; telegram from Secretary of State, Robert Lansing, to American Consul, Dawson. Information was received by Lansing from the Department of Navy, 18 June 1917; 812.50-1/114; telegram from Dawson to the Secretary of State, Lansing, 16 July 1917; for the strike's progression and activities also see El Rebelde (Los Angeles). 11 August 1917.

30 Ibid., 812.504/116; letter from Pieree Oil Corporation Vice-President, Eben Richards, to Assistant Secretary of State, Frank L. Polk, 24 July 1917. Reply was given to Pierce Oil from the State Department on 27 July 1917. For MTW Loeal \#100's activities during the 1917 strike, see El Rebelde (Los Angeles), 11 August 1917.

${ }^{31}$ Ibid., 812.504/117; telegram from Dawson to the Secretary of State, 24 July 1917.

32 Ibid., 812.504/117; telegram to Mexican Petroleum Company, New York, NY, from Gcorge Paddleford, local manager in Tampico, 26 July 1917.
} 
Responding to American company pressures and reacting to the strikers' refusal to quit, authorities ordered 300 troops to Tampico from the provincial capital, Ciudad Victoria. The troops arrived in Tampico on $24 \mathrm{July}$, and company officials along with the state Governor arranged a meeting for the following day. Upon arrival, an American Naval officer, Captain David Richardson, met with the region's new military commander, General Francisco Guerre, and the two discussed the IWW. Richardson informed Guerre that the IWW did not respect his or the Governor's authority and described it as an organization bent on the destruction of private property. He added further that "good" labor unions in the United States opposed the IWW and its tactics. Richardson, when referring to the "good" labor unions in the United States did not specifically mention the AFL, but it can be assumed that this is what he meant since the AFL had acquiesced to the American government's persecution of the IWW during World War I. He also urged Guerre that he should relate this information to the state Governor at their meeting the next morning. ${ }^{33}$

When the Governor, General Guerre, and oil company representatives arrived for the meeting the next day, they discovered that several IWW leaders were already in the office and that a crowd of angry strikers had surrounded the building. The company representatives repeated that they would not meet with IWW members, but only with a committee of what they called "regular" workers. They were also emphatic about their refusal to accept conditions outlined in a 12 July 1917 letter sent to them by IWW leaders, Francisco Gamallo and Ramon Parreno.

The letter called for immediate raises and union recognition. Company officials also insisted that they would not meet with any committee until all strikers had returned to work. After company officials left, Governor Ricaut attempted to defuse the situation. He promised to hold another meeting with strike representatives the next morning. ${ }^{34}$ But shortly after the meeting broke up and the crowd outside dispersed, Ricaut ordered Commander Guerre and his troops to surround IWW headquarters and arrest Wobbly leaders. Soldiers apprehended seventeen IWW members in all, leaving the strike's leadership decimated. By the end of the month, all strikers had returned to their jobs. The oil companies expressed their appreciation to the United States Department of State and praised Governor Ricaut's "handling" of the volatile situation. ${ }^{35}$

${ }^{33}$ Ibid., 812.504/124; Special Situation Report from Captain Richardson, Commander of Mexican Patrol, to the Department of Navy, 25 July 1917.

H Ibid.

3s Ibid., 812.504/124; telegram sent to Naval Operations Office, Washington, DC, 30 July 1917 from the U.S.S. Annapolis. Also see 812.504/124; letter sent from Pierce Oil Corporation, Vice-President, Eben Richards to the Acting Secretary of State, Frank L. Polk, 2 August 1917. For the arrest of IWW members see El Rebelde (Los Angeles), 11 August 1917. 
Despite their defeat, the IWW continued to agitate in Tampico. Workers called for a general strike on 15 November to win the release of three organizers jailed during the previous wave of persecution. Once again, Governor Ricaut intervened and threatened the IWW with more arrests if the strike continued. When the Wobblies refused, 200 troops arrived in Tampico from Ciudad Victoria and guarded the foreign-owned company's property with machine guns. Ricaut then declared martial law and prohibited demonstrations on Tampico's streets. He also ordered the arrests of two prominent IWW leaders and had troops surround Wobbly headquarters. He then forbade the organization from holding any public meetings in the Tampico area.

Despite the ban, the IWW organized Petroleum Workers' Local Union \#230 and Construction Workers' Local Union \#310. The locals conducted secret weekly meetings in the small industrial village of Doña Cecilia, once the scene of intense mutualista activity. Wobblies Víctor Martínez, Ramón Cornejo and José Zapata, continued to cooperate with the Tampico Casa and the Grupo Hermanos Rojos, which published El Pequeño Grande. ${ }^{36}$ The Wobblies joined the Casa in denouncing the growing partnership between the AFL and the CROM. In the IWW's new Spanish language newspaper, La Nueva Solidaridad, Jorge D. Borrán of the Tampico Casa attacked AFL-style unionism's penetration of Mexico. Borran stated that the laboring people of the western hemisphere had nothing to gain from AFL affiliation, an organization that he accused of being filled with lawyers, "parasites", and members of the bourgeoisie. Borran also defended the IWW against AFL and CROM attacks, and called for the release of Wobbly prisoners held in US jails. ${ }^{37}$

For the next three years the Wobblies cooperated with other anarchosyndicalists and remained active in the Tampico area. In July 1920 the IWW led a general strike of 10,000 workers for higher wages and better working conditions. It came after oil workers at Minatitlán, Veracruz, won wage concessions from the British-owned El Aguila Oil Company..$^{38}$ The Veracruz workers' organizational development paralleled that of the Tampico workers. Mutualist groups eventually evolved into gremios that represented the interests of both skilled and unskilled workers. Ultimately, some gremios won individual contracts with the companies, and in 1924 several of them joined together and formed the League of

\footnotetext{
36 NARAW, SD Records, RG 59, 812.504222; telegram from Consul Dawson at Tampico to the Secretary of State. 9 July 1920; for the IVWW's role in the strike and their cooperation with El Grupo Hermanos Rojo, see Solidarity (Chicago), 10 January 1920.

37 La Nueva Solidaridad (Chicago), 14 October 1919; also see the text of Borrán's statement in US Congress and Senate, Investigation of Mexican Affairs, 1919-1920, pp. 2826-2828.

34 Julio Valdivicso Castillo, Historia del movimiento sindicato petrolero en Minatillán. Veracruz (Mexico, DF, 1963). pp. 24-25; also see Francisco Colmenares, Petrolero y lucha de clases en Mexico, 1864-1982 (Mexico, DF, 1982), pp. 43-44.
} 
Workers' Groups of Minatitlán. The Tampico strike, while not successful, alarmed American authorities in the area. The American Consul in Tampico blamed the region's labor unrest on the ambivalent attitude of the Mexican government. He called for government officials to exercise a more interventionist role in labor relations, stating that such a strategy would guarantee the protection of American economic interests. ${ }^{39}$

Despite the American Consul's calls for order, the radicals continued to protest the government's actions. In Veracruz, stevedores conducted a two-hour work stoppage, while in Tampico the IWW held mass meetings in the city's central plaza. Alarmed at the tense situation, the Tampico authorities used troops, and violence ensued. Soldiers attacked the crowd and arrested several IWW leaders. The next evening local labor leaders representing the IWW's petroleum and construction workers' unions, the National Association of Molders and Helpers, and the Federation of Port Workers, called for a general strike to protest against the recent deportations and the violence in the city's central plaza on the night of 2 July. ${ }^{40}$

On 5 July Tampico workers responded to the call and the community came to a standstill. American petroleum companies petitioned the US State Department for protection of American lives and property. As the American government responded by sending two naval vessels to the area, the companies protested against the Mexican government's recent new tax increase levied against them. Reacting to the labor unrest, the companies locked out 20,000 workers. In an effort to defuse the tense situation, government authorities offered Tampico's workers free tickets for passage to other areas of the republic. Thousands of workers left Tampico and never returned. The lockout was the beginning of a permanent workforce reduction by the companies. ${ }^{41}$ Although authorities had successfully driven the Wobblies from the area, the IWW had helped to initiate the beginnings of union organization.

In August 1920, the IWW joined anarchosyndicalists and communists and helped to create a "Revolutionary Bloc", called the Communist Federation of the Mexican Proletariat (FCPM). The group's goal was to fight AFL-style unionism in Mexico and eventually unite all radical labor organizations. In February 1921, the FCPM met in Mexico City and organized the CGT. The CGT consisted of fifty unions with over 36,000 members. It rejected participation in politics, advocated direct action and promoted decentralist organization. The CGT also accepted

39 NARAW, SD Records, RG 59, 812.504/222; telegram from Consul Dawson at Tampico to the Secretary of State, 9 July 1920.

4 Solidaridad (Chicago), 18 June 1921.

"S. Leif Adelson, "Coyuntura y conciencia: Factores convergentes en la fundación de los sindicatos petroleros de Tampico durante la década de 1920". in El trabajo y los trabajadores en la historia de Méxicol Labor and Laborers through Mexican History (Tucson, Atizona, 1979), p. 640 . 
the participation of the Communist party and the idea of a workers' state, as long as power was exercised by the workers themselves, and not by a political party. ${ }^{42}$

Initially, the IWW, represented by North American Michael Paley, Jose Refugio Rodríguez and Wenceslao Espinoza, declined to join the CGT. The Wobblies argued for a centrally-controlled organization based exclusively in the workplace. They also stressed that workers' unity depended on the establishment of industry-wide industrial unions. ${ }^{43}$ In May 1921 the IWW and the CGT united in the face of government repression. The CGT-IWW alliance crumbled when the Obregon deported several key foreign-born organizers from both organizations. ${ }^{4}$

Despite the repression, the IWW's legacy of industrial unionism came to fruition in the Tampico region. By the mid-1920s, many foreign-owned companies had signed contracts and recognized unions. Where workers established trade unions, they initially affiliated with the CROM, but only as a means to increase their leverage against the companies. They ultimately rejected government tutelage and CROM affiliation and looked to organizations like the Sindicato Unico de la Region Petrolera and the Sindicato de Obreros y Empleados de la Compañía de Petróleo "El Aguila" to negotiate higher wages and better conditions." 193193 the industry counted thirty-five independent oil workers' unions. The workers' insistence upon union autonomy reflected the Casa and IWW's influence. Building upon what the Wobblies had achieved were local theatre groups presenting the dramatic works of Emile Zola and Ricardo Flores Magón. After his release from prison by American authorities in 1923, Ricardo's brother, Enrique Flores Magón, returned to Mexico, published Resurgimiento and agitated among the workers at Villa Cecilia. ${ }^{46}$ Together these forces played an instrumental role in raising the consciousness of Tampico's workers and establishing unions in a peripheral area of global capitalism. In the Mexican petroleum industry, the IWW facilitated labor's transition from gremio and mutual organization to fully-fledged trade unionism and industry-wide organization.

\section{WOBBLIES AND MEXICAN MINERS IN THE US}

Across the border in the United States the IWW's influence among Mexican workers, especially miners, had grown since the advent of the

12 Paco Ignacio Taibo II, Los Boishevikis: historia narrativa de los orlgnes del comunismo en México, 1919-1925 (Mexico, 1986), pp, 113-116.

3 lbid., pp. 113-116, 137, 141.

" Paco Ignacio Taibo II, "El breve matrimonio rojo: comunistas y anarchosyndicalistas en la CGT en 1921", Historias: revista de la dirreción de estudios historicos del Instituto Nacional de Antropologla e Historia (Mexico, DF, 1984), p. 50.

${ }^{43}$ Adelson, "Coyuntura y concicncia", p. 640.

46thel Duffy Turner, Ricardo Flores Mlagón y el Partido Liberal Mexicano (Morelia, 1960), p. 359. 
Spanish language IWW press there. ${ }^{47}$ Newspapers such as La Union Industrial, Huelga General, and El Rebelde had spread the IWW's ideas among Mexicans in the United States. By 1917 over 5,000 Mexicans belonged to IWW mining locals in the United States. ${ }^{48}$ The Wobblies built upon the organizational efforts of the PLM in the border areas. Through Regeneracion, the PLM's newspaper, Mexican workers had learned of the magonista opposition to the company store and wage disparity between Mexicans and North Americans.

The ideas that appeared in Regeneracion reflected the growing radicalism of the PLM's magonista faction. By the time of their self-imposed exile in the United States, Ricardo Flores Magón, Praxedis Guerrero and others had abandoned nationalistic liberalism and openly advocated anarchism. Contact with American radicals like Emma Goldman and Wobbly Ralph Chaplin reinforced their anarchist convictions and resulted in a commitment to organize Mexican workers, especially along the border. Magonista propaganda made headway among Mexican miners working the vast mineral regions that stretched across the American west into northern Mexico. PLM clubs were especially visible in the mining communities of Sonora and Arizona, like those started by Lázaro Gutiérrez de Lara in Cananea, Sonora, and Praxedis Guerrero's Obreros Libres in Morenci, Arizona. In 1906 miners following the leadership of the PLM and the WFM struck the Cananea complex and called for wage equity with foreigners. By 1915, the PLM's focus on economic discrimination had helped to mobilize a Mexican workforce for "direct action" against large mining enterprises and the government of the United States. With the Flores Magon brothers on trial in 1916 for violation of US neutrality laws, Mexican workers in the US looked increasingly to the IWW.

The IWW's influence grew in the mining regions of the American south-west because they confronted falling wages, poor living and working conditions, and a management system that practiced discrimination against them in the workplace. In early January 1917, 1,000 Mexican, Indian and Anglo workers struck mining operations in Ajo, Arizona. They demanded higher wages and refused to accept an agreement negotiated by the AFL's International Union of Mine, Mill, and Smelter Workers (IUMMSW). The workers rejected the agreement with the mining companies because it provided a sliding scale between $\$ 1.50$ to $\$ 2.50$ per day for miners working underground and on the surface. They considered the wage increases paltry and discriminatory. Local authorities

"NARAW, SD Records, RG 59, 812.504/151; letter from American Consul, Dawson, to the Secretary of State, 21 November 1917; also see 812.504/154; telegram from U.S.S. Annapolis to the Department of Navy, Washington, DC, 11 February 1918.

4 Ricardo Romo, "Response to Mexican Immigration, 1910-1930", Azfldn, 6, no. 2 (Summer 1975), pp. 186-187; Rodolfo Acuna, Occupied America: A History of Chicanos (New York, 1988, 3rd ed.), p. 166. 
received the cooperation of the IUMMSW's leadership when they arrested twenty-six miners, whom the union leadership and local press called "outside agitators".49

Despite the repression, Mexican miners continued to organize for higher wages and better conditions. They also bolted the IUMMSW because of that union's refusal to back their demands. Mexican miners at Clifton-Morenci, Arizona, began leaving the IUMMSW's predecessor, the WFM, as early as 1916 , after it failed to back a walkout. The increasingly cautious position of the WFM, which led to the creation of the IUMMSW, was largely due to the policies of the union's president, Charles H. Moyer.

Moyer had been an IWW leader and one of the founders of the WFM, but had adopted a more cautious strategy toward organizing workers after authorities released him and IWW leader "Big" Bill Haywood from prison. Haywood and Moyer remained in jail during their trial for the murder of Idaho Governor, Frank Steunenberg. Although the jury found both men not guilty, the jail experience radicalized Haywood and steered Moyer toward reformism. While Haywood continued in the IWW, Moyer joined the AFL. In February 1917 he revoked the Arizona AFL's IUMMSW charter, claiming that the "district's attitudes were too radical and independent". ${ }^{50}$ Afterwards, miners joined the IWW's Metal and Mine Workers' Industrial Union \#800. By May 1917 most Mexicans had abandoned the AFL and joined the IWW union. ${ }^{31}$

From 15 to 17 June 1917 , Industrial Union $\# 800$ held its first state-wide convention in Bisbee, Arizona, and discussed strategy to confront the copper companies. The $\mathbf{5 0 0}$ members in attendance called for: the abolition of the physical examination; two men to work on each machine; two men to work on raises; discontinuation of all blasting during a shift; abolition of all bonus and construction work; replacement of the sliding scale of wages with a flat daily rate of $\$ 6.00$ for all men working underground; and no discrimination against members of any organization. ${ }^{32}$

The demands reflected a desire among miners to exercise control of their work environment and their communities. As in Tampico, where the foreign-owned petroleum companies exercised power over the entire community, the Phelps-Dodge Corporation dominated the Arizona copper range. Besides owning the state's largest mining operation, the Copper Queen, Phelps-Dodge also owned the largest hotel, the hospital, department store, library, newspaper, and a host of other smaller enterprises.

\footnotetext{
49 "The Strike at Ajo", Mtiners' Magazine (Denver), January-February 1917; also see Philip S. Foner, Labor and World IVar 1, 191 $1-1918$, in the History of the Labor Mfovement in the United States (New York, 1987), vol. 7, pp. 265-266.

"lbid.

"Ibid.

52 lbid., p. 267.
} 
The Mexican miners' fight against the arbitrary power of Phelps-Dodge in the workplace evolved into a struggle that encompassed the entire communities where they lived and worked. Mexican miners had worked the Arizona range for years and were quick to demand their perception of "rights". The demands for decent wages and better working conditions were accompanied by calls for affordable housing and food. The occupational hazards that the miners suffered created a unique sense of unity not found among other groups of industrial workers. The tightness and isolation of the mining communities and the dangerous working conditions miners encountered produced a strong propensity to strike. ${ }^{33}$

Wobbly unions also spread to other locations on the Arizona mining range. In Jerome, Arizona, Mexican miners established a Metal and Mine Workers' Local after the IUMMSW failed to back their demands for higher wages and better conditions. When the United States entered the European war, the IUMMSW fell completely out of favor with the miners after its parent affiliate, the AFL, pledged not to strike for the remainder of the conflict. ${ }^{54}$

On 5 July 1917, the IWW called a strike and demanded six dollars for a six-hour day. While the IUMMSW called the demands "absurd", "unpatriotic", "disloyal", and "disruptive" to the war effort, both Mexican and Anglo miners supported them and stopped working. Since 1914, the beginning of the European war, orders for strategic minerals had been pouring in from the Allies, particularly Britain. To fill them, mining management ordered around-the-clock production, increasing miners' hours, but at the same time holding wages at pre-war levels, and allowing working conditions to deteriorate. As the owners' profits soared, miners were in no mood to compromise their right to strike and follow the dictates of the IUMMSW..$^{\text {ss }}$

The management at Jerome shared the sentiments of the IUMMSW and those of L.C. Shattuck, general manager of the Shattuck Arizona Company in Bisbee. A month earlier he had called the demands of the IWW a "conspiracy by enemies of the United States government to restrict or cut off the copper output required to prosecute the war".\$6 In Bisbee, like Jerome, local law enforcement officials and vigilantes responded to strike activity violently, particularly against the Mexicans. While deporting many Mexicans back to Mexico, local authorities and vigilantes dumped 1,200 strikers in the middle of the desert with no food or water, and prohibited them from returning to Bisbee. ${ }^{57}$ On 10

" Clark Kerr and Abraham Siegel, "The Interindustry Propensity to Strike: An International Comparison", in Arthur Kornhauser, Robert Dubin and Arthur N. Rose, Industrial Confict (New York, 1954), pp. 189-212.

st Foner, Labor and World War I, p. 269.

ss Ibid.

t6 As cited in ibid., p. 267.

I7 Ibid., p. 273. 
July, five days after the strike began in Jerome, authorities and vigilantes "rounded up" sixty-seven "suspected leaders" of the walkout and deported them to Needles, California. Outraged by the vigilantism condoned by the authorities, radical union members at Globe-Miami and Clifton-Morenci lodged vehement protests to the Governor, but to no avail.ss

The Morenci miners responded quickly to the Bisbee and Jerome deportations because they had already experienced harassment from the Federal government in their battle against the management of the Arizona Copper Company, a Phelps-Dodge subsidiary. Abelardo Ordoñez, an IWW organizer, speaking before miners on 4 May 1917 at an open-air meeting on company property, cursed United States Department of Justice agents for trying to intimidate the men in the camp from striking. ${ }^{59}$ In Globe-Miami, Julio Blanco and José Rodriguez made speeches that raised similar accusations. After the Jerome and Bisbee deportations, Pedro Coria of Tampico IWW Local \#100, Tomás Martínez and B. Negreira, members of Los Angeles Local \#602, all joined the GlobeMiami leadership. Together they condemned the deportations and carried out propaganda through public speaking and the Spanish language IWW newspaper, $E l$ Rebelde. As repression escalated within the context of US domestic wartime hysteria, tensions heightened between the authorities, the copper companies, and the miners. ${ }^{60}$

On the heels of the Jerome deportation, the IWW leadership made frequent speeches that called on workers to resist the "authoritarianism" of the companies and the officials of local, state and national government. On 6 July 1917, José Rodriguez spoke before a crowd of over 300 and said that American corporations and the United States government had made Mexican workers "slaves". He urged them to join the IWW and claimed that it was the only organization prepared to unite workers the world over, regardless of their national origin. Rodriguez boasted that the US government did not have enough bayonets to suppress or stop the IWW. Speaking to the same audience, Julio Blanco called the American flag the "banner of oppression" and proclaimed that the red flag, the "banner of the workers of the world", belonged to them. In the same speech he also pledged that the companies would not get one pound of copper for the war effort, and that Mexican miners should

So Ibid., p. 275.

99 NARAW, Military Intelligence Division (hereafter cited as MID), RG 165, 10110-12; letter from M.H. McLeam, Manager of the Phelps-Dodge Corporation, Morenci, Arizona, 17 May 1917, to Agent, R.L. Barnes, Fort Sam Houston, San Antonio. Texas. In the letter MicLeam stated that he was working closely with Department of Justice Agent, Harris.

NARAW, MID, RG 165, 10110-85; page five (5) of a report prepared by Justice Department Agent, S. Guzmín on "IWWW activities in the Globe-Nliami District", 25 September 1917. 
view their fight for better wages and conditions as part of a world-wide battle against a class that "slaughtered" their brothers on the battlefields of Europe. ${ }^{61}$

Blanco and Rodriguez escalated their attacks against the American government after the lynching of IWW miner and organizer, Frank Little, in the mining region of Butte, Montana. Addressing crowds of 1,200 men, they directed their remarks personally at President Woodrow Wilson, calling him a man dedicated to the "enslavement" of the working class. ${ }^{62}$ Little's murder and the deportations at Jerome and Bisbee served as an organizational catalyst for the IWW in the Globe-Miami region. Weekly meetings began to attract over 1,000 miners and smelter workers at a place that became known as "Wobbly Hill". The IWW enjoyed the support of Italians, Finns, Poles and Anglos, in addition to the Mexicans, who constituted the union's leadership core. ${ }^{63}$ By September 1917, when the IWW local at Globe-Miami struck the companies for better wages and conditions, the union had grown to over 700 duespaying members. United States Military Intelligence personnel identified forty-two Mexican miners as the leading agitators of the strike. ${ }^{\text {at }}$

The IWW's Spanish language press exercised a key role in educating the workers and triggering the strikes. Mexican IWW organizers, Julio Castillo, Tomás Martínez and Pedro Coria established closer ties between Mexican workers in the United States, the northern mining regions of Mexico, and the oil producing region of Tampico, by distributing IWW Spanish language newspaper, El Rebelde. ${ }^{65}$ Because of their activities, Martínez and other IWW leaders fell victim to the wholesale arrests carried out by US Justice Department officials and local police.

On the afternoon of 22 March 1918, authorities arrested Martínez and B. Negreira, members of Los Angeles IWW Local \#602, and frequent contributors to El Rebelde. Justice Department officials simultaneously shut down the paper and arrested its editor, Aurelio Azuara ${ }^{66}$ Although El Rebelde's forced closure dealt a severe blow to the IWW's Spanish language propaganda machine, José Vásquez, a Spanish anarchist and

'Ibid., excerpts of Rodriguez and Blanco's speeches are found in S. Guzmán's report on "IWW activities in the Globe-Miami District", under the subtitle, "Prominent Members and Officials of the IWW Movement".

62 Ibid., 10110-13, report from S. Guzmán on "IWW activities at Globe-Miami", 14 March 1918.

${ }^{63}$ Ibid., 10110-85, report from S. Guzmán on "IWW activities in the Globe-Miami District", 25 September 1917.

64 Ibid.

as Ibid., 10110-12, report from agent, John W. Ganzhorn on "IWW activities at Globe and Vicinity", 24 February 1918.

'Ibid., 10110-13, report from S. Guzmán concerning the arrests of IWW agitators, Azuara, Martínez and Negreira, 22 March 1918. For a sample of Martínez's contributions to El Rebelde, see "Latigazos a los mártires de la A.S.F. of L. de Morenci, Arizona, Local \#2", in El Rebelde (Los Angeles), 26 December 1915. 
close friend of Negreira, began distributing El Hombre Libre, an anarchist paper printed in Spain and distributed in Mexico. ${ }^{67}$ But the Mexican miners in Arizona never recovered from the repression, which reached its apex on 6 October 1918, when the United States Congress passed the Alien Act. ${ }^{68}$

In effect, the Alien Act sanctioned the Bisbee and Jerome deportations, the arrests of Martínez and others, and the subsequent expulsions of hundreds of foreigners suspected of subversive activity. The passage of the Alien Act and its strict enforcement meant that Mexican miners had to accept wartime production conditions or face deportation. In addition, the Federal government sanctioned IUMMSW contracts with the copper companies that pledged not to interfere with the war effort by stopping production. The agreements also contained a provision that stated "no employment should be made available for IWW members or for other persons who had been guilty of disloyal utterance against the United States". 69

The IUMMSW praised the agreement and threatened to cancel the charter of any local that did not accept it. ${ }^{70}$ After the strikers returned to work and industrial peace prevailed in the mining camps, the companies stretched the agreement and refused to recall anyone "whose employment for any reason is contrary to the best interests of the operations".71 Mining management then refused to employ any man who belonged to a union, even the IUMMSW, and operated the mines as open shops. As the copper companies and the American government crushed labor organization in the mining regions of Arizona, the anarchosyndicalists continued to organize workers inside Mexico.

\section{WOBBLIES AND MINERS INSIDE MEXICO}

The IWW organized miners and smelter workers in Guanajuato, Hidalgo and Coahuila, and intensified its activities in Chihuahua and Sonora. In July 1920 at Pachuca, management at the American-owned United States Smelting, Refining, and Mining Company complained about the widespread distribution of IWW literature. Company officials blamed the IWW for a recent strike by 4,000 workers who demanded higher wages and the dismissal of an American foreman. ${ }^{2}$ In late November 1920,

"Ibid., 10110-12, report from agent, S. Guzmón on "IWVW activities in Globe-Miami", 6 March 1918.

Goser, Labor and World War 1, p. 279.

Ibid., p. 280.

7 lbid.

7 lbid.

7 NARAW, SD Records, RG 59, 812.504/152, letter to R.C. Tanis, Division of Mexican Affairs, US State Department, from IVilliam Yeandle, Jr of the United States Smelting. Refining and Mining Co., 5 December 1917. 
American mining companies operating in Chihuahua said that the region had been overrun by radical labor agitators. Management called them "Arizona-Mexicans", IWW members and veterans of strikes that had swept the border region since 1903." "Arizona-Mexicans" had been paid twice as much in the United States as in Mexico. Now working south of the border they demanded higher wages and an end to abusive management practices. ${ }^{74}$

The militant posture of the Mexican miners was rooted in their early resistance against ethnic segregation, forced proletarianization, isolation and dependence on foreign capital, all characteristics of the mining enclaves created in northern Mexico, and beginning in the 1890s. Skilled miners that had worked the Mexican ranges since the colonial period organized mutualistas in the nineteenth century. But as foreign capitalists reorganized labor at the turn of the century, anarchist propaganda reached unskilled miners. With the open collaboration of the WFM, the PLM enlisted Mexican miners as one of its strongest social bases of support. By 1906, the year of the Cananea uprising, Mexican miners viewed anarchism and syndicalism as the formula for working-class unity. Even after the overthrow of Diaz in 1911, Mexican miners formed their own organizations independent of the government. The most important of these organizations was the Union Minera Mexicana with its sixteen affiliates. ${ }^{75}$

From 1911 to 1918, the Union Minera Mexicana maintained its organizational independence. Rather than send members to fight in the Casa del Obrero Mundial's Red Batallions alongside the reformist factions of Venustiano Carranza and Alvaro Obregón, the miners fought for an end to the company store, higher wages and union recognition. Much of the miners' organizational independence resulted from their geographical isolation. Unlike workers in Mexico City for example, the miners' confrontations with state authority were few in number. Instead, the miners pressured local authorities to back their demands of the foreign companies. The miners' agitation produced local legislation favorable to labor. Some of the legislation became part of Article 123 of the 1917 Constitution which, among other things, gave Mexican workers the right to strike and the eight-hour day. ${ }^{76}$ Although coal miners from Coahuila represented the

3 NARAW, MID Records, RG 165, 10058-0-9; letter from C.D. Garrison, Army Intelligence Officer, Douglas, Arizona, to A.C. of S. for M.1. 8th Corps Area, Fort Sam Houston, San Antonio, Texas, 15 November 1920. For a chronology of the IWW's activities in Sonora, Cananea, Chihuahua and Arizona see El Rebelde (Los Angeles), 15 March 1915; letter from Tomás Martínez, "Compañeros de la Unión Obrera de Cananea, ¡Alerta! in El Rebelde, 28 August 1915; also see Luz (Mexico City), 1 May 1919, letter from IWW members Benito Pavón, Edmundo Ibarra and Pablo Ollo to editor, Jacinto Huitrón.

74 NARAW, MID Records, RG 165, 10058-0.9; letter from Garrison to M.I. 8th Corps Area, Fort Sam Houston.

${ }_{75}$ Besserer, Novelo and Sariego, El sindicalismo minero, pp. 23-24.

76 lbid., pp. 24-25. 
Union Minera Mexicana at the founding convention of the CROM in 1918, they were the first to abandon its ranks in 1923, when it created the Partido Laborista and supported Alvaro Obregón for the presidency. ${ }^{n}$ Despite its efforts, the Union Minera Mexicana remained a loose confederation composed of skilled, semi-skilled and unskilled workers in copper, zinc, lead and coal mining. It failed to unite these workers into an industry-wide union that coordinated simultaneous strike activity around a set of universal demands.

By its insistence upon independent industry-wide unionism, the IWW filled an organizational void and made itself attractive to Mexican miners. The Wobblies' history of struggle for Mexican miners' "rights" in the United States also facilitated its organizational efforts inside Mexico. Two decades of Mexican miners crisscrossing the border had led to the proliferation of Wobbly propaganda inside Mexico. For Mexican miners, the IWW's strategy and tactics had already been tested at Cananea and across the border in the United States. The Wobblies' message resembled that of the PLM's, the Casa's and other working-class organizations rooted in the Mexican anarchosyndicalist tradition. Beginning in the 1920s, when mining companies tried to enforce a "new" work discipline, the IWW attempted to direct Mexican miners' resistance.

Miners began a series of strikes at the Rockefeller-controlled Cananea Consolidated Copper Company on 5 October 1920. IWW organizer Antonio C. Ramírez led them on strike in protest of the company's noncompliance with a labor law passed by the state of Sonora in 1916. Although management accepted the law that placed the maximum length of a shift in a mine for seven hours, it refused to pay the miners for eight hours work. Workers also demanded the dismissal of abusive American foremen. The walkout lasted nearly three weeks and turned violent when strikers shot an American foreman. Afterwards, the acting Governor of Sonora, A.M. Sánchez, sent in 250 troops. Finally, the government intervened and used arbitration to settle the dispute. ${ }^{78}$ The actions of IWW organizers at Cananea harkened back to 1906 when the WFM and the PLM led miners on strike over some of the same issues: poor conditions and discriminatory practices by foreign managers. Like Cananea in 1906, the government used force to subdue the strikers. This time, however, the miners, through the Union Minera Mexicana, already had fought for and won laws that protected workers on the job. The miners at Cananea followed IWW organizers because "direct action" obliged the government to enforce those laws.

Although it settled the dispute at Cananea, the government refused to stop a seven-week-long lockout by Guggenheim management in the Santa

$\pi$ lbid., pp. 25-26.

"NARAW, SD Records, RG 59, 812.504/260; letter from American Consular Agent, J.M. Gibbs in Cananea to the Secretary of State and to the American Consul, Francis 
Barbara district near Parral, Chihuahua. The lockout was a response to a strike in a mine led by IWW agitators Elfredo Lugo and Albert Fodor, former editors of the Arizona Labor Gazette. With government troops guarding the mines, company officials imported replacement workers, despite the fact that some soldiers threw down their weapons and joined the strikers. When the companies secured enough men to operate the mines, they made non-wage concessions, while the authorities drove the IWW organizers from the area. ${ }^{79}$

But the Chihuahua area remained fertile ground for organizing. There the Wobblies organized miners and smelter workers employed by the Guggenheim-owned American Smelting and Refining Company (ASARCO) and the El Potosí Mining Company. The union's campaign began at the ASARCO complexes in Santa Barbara, where management had been promoting unions of "free workers". There the Wobblies had been conducting propaganda among the workers through distribution of their new Spanish-language newspaper, Solidaridad. The miners were receptive to the idea of "One Big Union" and IWW organizer, Eduardo Modesto Flores, successfully organized Metal Miners Industrial Union \#210. ${ }^{80}$

Solidaridad, the union's North American Spanish-language newspaper printed in Chicago, reported a rapid increase in circulation during 1923 and 1924 when thousands of Mexicans trekked northward to take jobs in American industry. Restrictive immigration legislation passed in the United States kept Europeans out, but not Mexicans, and employers recruited them to work America's mines, factories and fields. During the 1920s, Mexicans in the United States found the IWW willing to organize them while the AFL was not. As the cross-border flow of Mexican workers increased, Solidaridad found its way into the Mexican mining districts. Solidaridad helped organizers build on more informal contacts between workers in the mining communities of Chihuahua and laborers elsewhere. Central to the paper's effectiveness as an agitational tool was the news it carried about political prisoners in the United States, many of whom were Mexicans. ${ }^{81}$

J. Dyer at Nogales, Sonora, 6 October 1920. Agent Gibbs states in the letter that he received the information from Cananea Company officials, George Young and T. Evans. 7 NARAW, MID Records, RG 165, 10058-0-9; letter from C.D. Garrison, Intelligence Officer, Douglas, Arizona, to Headquarters, Fort Sam Houston, San Antonio, Texas, 15 November 1920.

${ }^{80}$ NARAW, SD Records, RG 59, 812.504/520; letter from American vice-consul at Chihuahua, Thomas McEnelly to the Secretary of State, 8 November 1923. McEnelly worked closely with J. Norris Hobart, ASARCO's welfare representative, who complained of constant IWW agitation at company facilities in Chihuahua. For the IWW's continuing efforts to organize Mexican miners see Solidarity (Chicago), 2 June 1923. For the formation of Miners and Smelter Workers' Industrial Union \#210, see Solidaridad (Chicago), 5 April 1924.

s1 Solidarity (Chicago), 2 June 1923. 
On 1 May 1923, railroad unions held a mass rally and demonstration at the American Consulate in Chihuahua. There speakers demanded the release of sixty-one Mexican prisoners held in American jails. While remembering the Haymarket anarchists of 1886, the union leaders attacked "free" workers' associations and Catholic unions, both of which had been used by management to forestall the organization of workers by more radical unions. Rafael Gómez, president of the local executive committee of the Federation of Railway Unions of the Republic of Mexico, read an open letter to American President, Warren G. Harding. He demanded the release of Mexican IWW members, Aurelio Azuara (former editor of $\mathrm{El}$ Rebelde), Manuel Rey, Tómas Martínez, and Félix Cedeño, all of whom had been prominent members of Mexican IWW Local \#602 in Los Angeles, California. ${ }^{82}$

Using Solidaridad, IWW organizers escalated their efforts to organize Chihuahua's miners. The newspaper and literature focused on issues that had plagued Mexican miners for years: long hours, low wages, and abusive foremen who tried to implement company productivity schemes. Besides earning meager wages, which averaged around one dollar per day, miners and smelter workers had to buy their necessities at company stores at inflated prices. To protest the conditions and the firing of two of its members, IWW Local \#210 called for a strike at the El Potosí Mining Company in Santa Eulalia. Employees at Santa Eulalia responded, and the strike quickly spread to Avalos and eventually involved 5,000 miners and smelter workers. The strikers then demanded an end to all piece-work, a minimum wage of $\$ 2.50$ per day and the dismissal of two foremen. ${ }^{83}$

The IWW held public meetings throughout the mining districts of Chihuahua that eventually numbered as high as 3,000 . Company officials pleaded with local authorities to break up the meetings and force the strikers back to work. Local authorities finally acted on 11 May, when a contingent of thirty mounted rural guards charged a gathering of strikers at Santa Eulalia. During the scuffle police injured about a dozen people and apprehended seven strikers. The following day the IWW organized a march of over 300 people to Chihuahua City and demanded the freedom of the three arrested strike leaders. The next day Governor Reynaldo Talavera released Francisco Morales, Enrique Castillo, and Francisco Nuñez, all of whom had been principal strike leaders. ${ }^{8-4}$

The strikers then received help from the IWW's international office in Chicago. The North American IWW conducted a fund-raising campaign to help sustain them. Unions in Tampico also sent help to Chihuahua. Just when it appeared that the strikers had captured the initiative, local

- El Diario (Chihuahua, Mexico), 2 May 1923.

"NARAW, SD Records, RG 59, 812.504/565; letter from American Consul, Thomas MicEnelly to the Secrctary of State, 24 May 1924. Also see Solidarity (Chicago), 21 May 1924 and Solidaridad (Chicago), 12 July 1924.

"Ibid. 
officials and company management wielded the instruments of co-optation and repression. On 27 May, a group of "free" workers signed an agreement with ASARCO and the El Potosi Mining Company. It contained a number of concessions, including the minimum wage, and Sundays off. Piece-work provisions, however, remained. Mining management fired known IWW members and required all workers to sign contracts that prevented them from joining the IWW. Most of the workers returned to their jobs, but a sizable minority remained on strike. ${ }^{\mathrm{gs}}$

While the IWW chartered two new locals in Los Lamentos, authorities escalated their attacks on Wobbly meetings and demonstrations. During June 1924, police repeatedly attacked crowds beating people with clubs and pistols. On 30 June, they fired upon strikers at an open-air meeting and killed IWW leader Marcos Martínez. At the same meeting, police severely beat Pascual Díaz, secretary of Local \#210, and arrested IWW members Jesús González and Basilio Pedroza. The repression decimated the IWW's ranks in Chihuahua and marked the decline of the Wobblies inside Mexico. ${ }^{86}$

In mining, like the petroleum industry, the IWW's contribution to the establishment of permanent labor organization was significant. Although Mexican miners had organized themselves into mutualistas initially and then gremial organizations under the umbrella of the Union Minera Mexicana during the revolutionary period, an industry-wide confederation did not emerge until $1934 .{ }^{87}$ The Wobblies' activities represented an important period of organizational transition for Mexican miners. Like other anarchosyndicalist organizations in Mexico, the IWW agitated not only for the long-range goal of workers' control, but also raised immediate demands such as higher wages, better conditions, and union recognition. The Wobblies' presence reinforced the struggle by other Mexican miners' unions that eventually led to successful industry-wide organization. In mining, more so than petroleum, the IWW demonstrated its role in the organizational development of the working class on an international level.

\section{CONCLUSION}

Like other radical unions that attempted to organize Mexican workers during the revolutionary period, the IWW ultimately failed to forge an enduring organization. But its contribution to the development of the Mexican working-class movement and its future organization was significant. As Mexico opened its door to foreign investors, particularly from the United States, their economies and subsequently their labor

s NARAW, SD Records, RG 59, 812.504-567; letter from American Consul McEnelly to the Secretary of State, 27 May 1924. Also see Solidaridad (Chicago), 31 May 1924.

Ibid, 26 July 1924.

Ibid., p. 27. 
movements became more integrated. This was especially true in mining as the vast mineral region of the American west linked up with northern Mexico. The integration spurred a cross-border flow of Mexican workers who came into contact with radical labor unions like the WFM, and later the IWW.

When Mexicans returned home, they carried with them the tactics and strategies of American syndicalism and combined them with those of already existing radical labor groups inside Mexico. In 1906 the IWW established firm credibility among Mexican workers when it participated in the great Cananea uprising. Once inside Mexico the Wobblies cooperated with radical PLM members and the Casa del Obrero Mundial. By 1917 it had established locals among miners and smelter workers in the industrial centers of the Mexican north. These factors produced a potentially powerful industrial working class and facilitated the growth of the Wobblies inside Mexico.

During the late 1910s and early 1920s, the Wobblies continued to organize locals among miners and smelter workers. The IWW also played a crucial role in the establishment of the first oil workers' unions in Mexico. As a result the Wobblies became central to the tension that developed between foreign-owned petroleum companies and the Mexican government. The IWW enjoyed success not only because it advocated better wages and conditions, but also union autonomy, a concept rooted in the Mexican labor movement's anarchosyndicalist traditions. Along with other radical labor groups, the Wobblies defended the right to strike and fought for union independence against a government that attempted to harness the militancy of organized labor through the creation of state-backed labor organizations.

Because the Wobblies' presence was so prevalent in strategic profit making industries like mining and petroleum, its significance as a key player in the Mexican labor movement and the revolution cannot be overlooked. The study of the IWW and its impact on Mexican workers also provokes discussion on the larger issues surrounding the 1910 Revolution. The IWW's activities among Mexican workers on both sides of the border helps to better explain the shifting diplomatic, economic and political interests of foreign and Mexican elites and the militant role that organized labor played in the process and outcome of this century's first major social revolution.

Finally, the IWW in Mexico demonstrates clearly its efforts to organize workers on an international level. The Wobblies received support worldwide because they attempted to address the immediate needs of workers caught in an organizational transition between craft and industrial unionism. As world capitalism more thoroughly penetrated peripheral areas like Mexico, the IWW joined other organizations in leading workers to call for a decent living wage, better conditions and organizational recognition. For that reason alone, the IWW played an important role in a crucial transitional phase of international working-class history. 